\title{
A Multi-Generational Workforce: Managing and Understanding Millennials
}

\author{
Belal A. Kaifi ${ }^{1}$, Wageeh A. Nafei ${ }^{2}$, Nile M. Khanfar $^{3}$ \& Maryam M. Kaifi ${ }^{4}$ \\ ${ }^{1}$ Trident University International, California, USA \\ ${ }^{2}$ Menoufia University, Menoufia, Arab Republic of Egypt \\ ${ }^{3}$ Nova Southeastern University, Florida, USA \\ ${ }^{4}$ Los Medanos College, California, USA \\ Correspondence: Nile M. Khanfar, Nova Southeastern University, 11501 N. Military Trail, Palm Beach Gardens, \\ Florida 33410, USA. Tel: 1-561-805-2242. E-mail: khanfar@nova.edu
}

\author{
Received: September 11, 2012 Accepted: October 29, 2012 Online Published: November 28, 2012 \\ doi:10.5539/ijbm.v7n24p88 \\ URL: http://dx.doi.org/10.5539/ijbm.v7n24p88
}

\begin{abstract}
Generational diversity has become the norm in many organizations. As baby boomers retire and millennials enter and take over the workforce, it becomes imperative for managers to learn more about their job satisfaction and organizational commitment levels. The authors of this study surveyed 148 millennials who work in the I.T. industry. A total of 74 males and 74 females were surveyed. Results show that males have higher job satisfaction levels than their female counterparts and females have higher organizational commitment levels than their male counterparts. Furthermore, millennials with a graduate degree are more likely to stay at their organization than millennials without a graduate degree. Recommendations and implications are discussed for managers hiring, leading, and managing millennials in the workforce.
\end{abstract}

Keywords: millennials, management, job satisfaction, organizational commitment, education

\section{Introduction}

Over the past sixty years, there have been three generations, the Baby Boomer Generation, Generation X, and most currently Generation Y also known as millennials. As these various generations work side-by-side in the workplace, organizational behavior has changed to adapt to each generation. Managers are dealing with a generation that has a unique work ethic when compared to their more experienced colleagues. Interestingly enough, "organizations and researchers are just now beginning to address issues related to generational differences that may have a significant impact on the leadership and success of the organization" (Salahuddin, 2010 , p. 1). It becomes imperative to learn as much about the millennial generation as possible. Thus, this study strives to learn more about millennial job satisfaction and organizational commitment levels based upon gender and whether or not millennials with a graduate level degree are more likely to stay with an organization than millennials without a graduate level degree. Baby boomers are starting to retire and as a result more millennials are being hired throughout the nation. As such, the differences among the generations in the workforce can create some problems for managers who are responsible for making sure that tasks are being completed. As a matter of fact, differences "create problems among team members that ultimately result in reduced effectiveness" (Colquitt, Lepine, \& Wesson, 2011, p. 392). Table 1 depicts the three different generations currently in the workforce and when they were born:

Table 1. The different generations in the workforce

\begin{tabular}{lc}
\hline Generation & Date of Birth \\
\hline Baby Boomers & $1946-1964$ \\
Generation X & $1965-1980$ \\
Generation Y & Born after 1980 \\
\hline
\end{tabular}




\section{Literature Review}

This section will review the literature relating to the three different generations in the workforce. In order to correctly understand millennials, it becomes imperative to also understand their more experienced counterparts. As mentioned above, Baby Boomers were born in between 1946-1964 and are the largest group (representing approximately 79 million in the US) of the three generations (Rosenberg, 2009).

\subsection{Baby Boomers}

Baby boomers are the young American males who returned from tours of duty during World War II. Consequently, the young males started families resulting in a large number of new babies (baby boom) (Rosenberg, 2009). Baby Boomers born in United States were raised in a prosperous economic time. Baby Boomers are optimists who grew up expecting the world to progress and for the wars to end. After some of their icons were assassinated (e.g., Martin Luther King and the Kennedy brothers), this generation rejected traditional norms and values. Furthermore, this generation did not grow up dependent on technology. As a result, they view technology as "artifacts" of organizational culture (Simons, 2010, p. 31). In regards to understanding this group, Baby Boomers possess traits that are shared among the members of other generations. Baby boomers enjoy having the autonomy to focus on some their own hobbies (e.g., playing golf, gardening, volunteering, and just relaxing). The majority of Baby Boomers prefer having flexible work options, acknowledge the importance of work/life balance, and prefer to work remotely. Furthermore, Baby Boomers like to volunteer and help keep this planet healthy (Hewlett et al., 2009, p. 73). As the baby boomer generation prepares for retirement, the next generation (Generation $\mathrm{X}$ ) will be taking over many of those positions.

\subsection{Generation $X$}

According to Kane (2012), "Generation X encompasses the 44 to 50 million Americans born between 1965 and 1980. This generation marks the period of birth decline after the baby boom and is significantly smaller than previous and succeeding generations." This generation has unique traits. For example, they are often described as "individualistic, risk-tolerant, self reliant, entrepreneurial, comfortable with diversity, and valuing work life balance" (Gentry et al., 2011, p. 39). Some researchers have concluded that this generation can be less formal in certain situations. Generation X managers will typically be less formal, and more adaptable than their predecessors. Gen Xers tend to focus on outcomes rather than the process (Dols et al., 2010, p. 69). Other researchers have concluded that this generation lacks people skills. "For Gen X managers, the trait of independence comes with negatives; such as being impatient, having poor people skills, and working from a place of cynicism. They are also very straightforward and tend to lack people skills, which may affect employee retention" (Salahuddin, 2010, p. 4). As managers, this generation uses a contingent based style depending on the situation that they are facing. In one study, Generation X managers "labeled their leadership as situational," as opposed to boomers who discussed servant leadership (Salahuddin, 2010, p. 5). They prefer direction such as "do it your way", and "there aren't a lot of rules here" messaging, and utilize the same styles themselves as leaders (Gentry, 2011, p. 45). The next generation has proved to be a powerful force in the workforce because of their technological proficiencies.

\subsection{Generation Y - Millennials}

Millennials have grown up in the digital age. They show greater familiarity than previous generations with communication, media, and digital technologies. Because they are more "wired," this gives Millennials a competitive advantage and makes them an asset when it comes to working with new technologies. Tolbzie (2008), however, also points out that, "they are also sometimes called the "Trophy Generation" or "Trophy Kids" based on the emerging trend in sports and competition to reward everyone for participation, rather than for winning" (p.12). Because of this experience they have been said to reject in-house competition and politics. Furthermore, because many watched their parents be adversely affected by the dot-com bubble burst and high rates of divorce and layoffs, millennials are thought to be skeptical of long-term commitments, and are said to desire greater flexibility in their career. Members of this generation are described as preferring collective action, working in teams, wanting work that really matters to them, and being civic-minded, eco-aware, confident, conventional, optimistic, and socially conscious (Hewlett et al., 2009). One research study described millennials as "opinionated" and they "[expect] to be heard" (Hartman \& McCambridge, 2011, p. 24).

So if these are their traits as individuals, what are their traits as leaders? A study conducted by Gibson, Green, and Murphy (2010) identified the differences in management values between the generations, showed that the top five values for managers of Gen Y were: family security, health, freedom, self-respect, and true friendship (p. 39). This study also concluded that the management styles and values of the generations were more alike than different. A study by Hartman and McCambridge (2011) revealed that academic and business researchers 
concluded that the development and use of effective communication strategies is a critical skill set for all managers (p.36). These skills have been directly linked to both individual effectiveness (e.g., opportunities for promotion, special assignments, team effectiveness) and to organizational effectiveness and bottom line performance. Their study focused on university students of the millennial generation, which showed that although Millennials have been characterized as being technologically sophisticated and capable of multitasking, they are deficient in oral, written, and interpersonal communication skills. Thus, it becomes imperative to understand more about this generation who will be leading organizations of the future.

\section{Study Methodology}

A survey was distributed to 190 I.T. millennial employees at a hospital in California. Of the 190 surveys that were distributed, 148 surveys were completed by 74 males and 74 females. This represents a $77 \%$ response rate. This small population sample can simply be used as a pilot study because of the convenience sampling method which cannot be generalized to an entire population of 79 million individuals.

The research question for this study is: Are millennial males or females easier to manage in terms of job satisfaction, organizational commitment, and higher levels of education? The research hypotheses for this study are as follows:

H1: Both male and female Millennials will have the same scores as to job satisfaction.

H2: Both Millennial Males and Females will have the same scores in regards to organizational commitment.

H3: Millennials with a graduate degree are just as likely to quit their jobs as Millennials without a graduate degree.

For the purpose of this study, job satisfaction is defined as a positive emotional state resulting from the appraisal of one's job experiences and organizational commitment is defined as the aspiration on the part of an employee to remain a member of the organization.

\section{Study Results}

The following Table represents the number of participants in this study based upon gender:

Table 2. Number of particpants

\begin{tabular}{lc}
\hline Males & 74 \\
Females & 74 \\
$\mathrm{~N}=$ & 148 \\
\hline
\end{tabular}

H1: Both male and female Millennials will have the same scores as to job satisfaction.

Table 3. Job satisfaction mean scores

\begin{tabular}{lcc}
\hline & Male & Female \\
\hline Mean (Job Satisfaction) & 3.879 & 3.101 \\
Std. Deviation & .758 & .945 \\
\hline
\end{tabular}

Table 4. Job satisfaction: T-test and P-value

\begin{tabular}{lc}
\hline T-test & -5.472 \\
P-value (sig) & .000 \\
\hline
\end{tabular}

The first hypothesis, stating that both male and female millennials will have the same scores as to job satisfaction is rejected ( $\mathrm{t}=-5.472, \mathrm{p}=.000)$. As shown in Table 3, male millennials have a significantly higher mean in job satisfaction than female millennials. In this case, male millennials are more satisfied in their jobs than female millennials.

H2: Both Millennial Males and Females will have the same scores in regards to organizational commitment. 
Table 5. Organizational commitment mean scores

\begin{tabular}{lcc}
\hline & Male & Female \\
\hline Mean (Organizational Commitment) & 3.311 & 3.878 \\
Std. Deviation & .978 & .860 \\
\hline
\end{tabular}

Table 6. Organizational commitment: T-test and P-value

\begin{tabular}{lc}
\hline T-test & 3.750 \\
P-value (sig) & .000 \\
\hline
\end{tabular}

The second hypothesis, stating that both male and female millennials will have the same scores as to organizational commitment is rejected $(\mathrm{t}=3.750, \mathrm{p}=.000)$. As shown in Table 5, female millennials have a significantly higher mean in job commitment than male millennials. In this case, female millennials are more committed to their jobs than male millennials.

H3: Millennials with a graduate degree are just as likely to quit their jobs as Millennials without a graduate degree.

Table 7. Quitting job mean scores

\begin{tabular}{lcc}
\hline & Graduate Degree & No Graduate Degree \\
\hline Mean (Quitting Job) & 1.730 & 1.385 \\
Std. Deviation & .447 & .491 \\
\hline
\end{tabular}

Table 8. Quitting job: T-test and P-value

\begin{tabular}{lc}
\hline T-test & 4.324 \\
P-value (sig) & .000 \\
\hline
\end{tabular}

The third hypothesis, stating that millennials with a graduate degree are just as likely to quit their job as millennials without a graduate degree is rejected $(\mathrm{t}=4.324, \mathrm{p}=.000)$. As shown in Table 7, millennials with a graduate degree (mean=1.1730) are less likely to quit their job than millennials without a graduate degree $($ mean=1.385). In this case, millennials with a graduate degree are more likely to keep their jobs than millennials without a graduate degree.

\section{Discussion, Implications, and Limitations}

This study yielded useful results that can be used by practitioners and researchers to better understand the millennial generation. It is important to mention that millennials have specific traits that should be taken into consideration by managers. For example, Howe and Strauss (2008) explain several core traits of the millennial generation. Millennials are overachievers and are accountable for their actions. At times, they feel pressured to surpass all of their goals and aspirations. They are able to multi-task and improvise when needed. Thus, a manager should feel confident in delegating tasks to millennials. Furthermore, millennials are team-oriented and enjoy working with others. They have grown up in a diverse world and understand the importance of learning and embracing new perspectives in order to avoid groupthink. Millennials are confident and should be considered for leadership positions because of their overall mentality that has been molded by previous generations. Millennials like to have flexibility and dislike dealing with too many rules and regulations.

Based upon the results of this study, managers may want to consider hiring millennials with a graduate level degree because they may stay with the organization for a longer period of time. Interestingly enough, several studies indicated that individuals with a graduate level degree were more satisfied with their job than those without a graduate level degree (Azalea, Omar, \& Mastor 2009; Bjork et al., 2007). A graduate level degree may provide a millennial employee with additional confidence and a higher salary resulting in higher job satisfaction levels. 
The results of this current study also yielded that millennial males have higher job satisfaction levels than their female counterparts. This may be a result of the glass-ceiling phenomenon where women face a glass-ceiling in upper management positions resulting in lower job satisfaction levels. Furthermore, men still dominate the workforce and as a result have more opportunities for advancement. It is also a known fact that there is a salary disparity between men and women. The following chart shows the anticipated first-year salaries of male and female undergrads (Casserly, 2012). As can be seen below, males make approximately $15 \%$ more than their female counterparts.

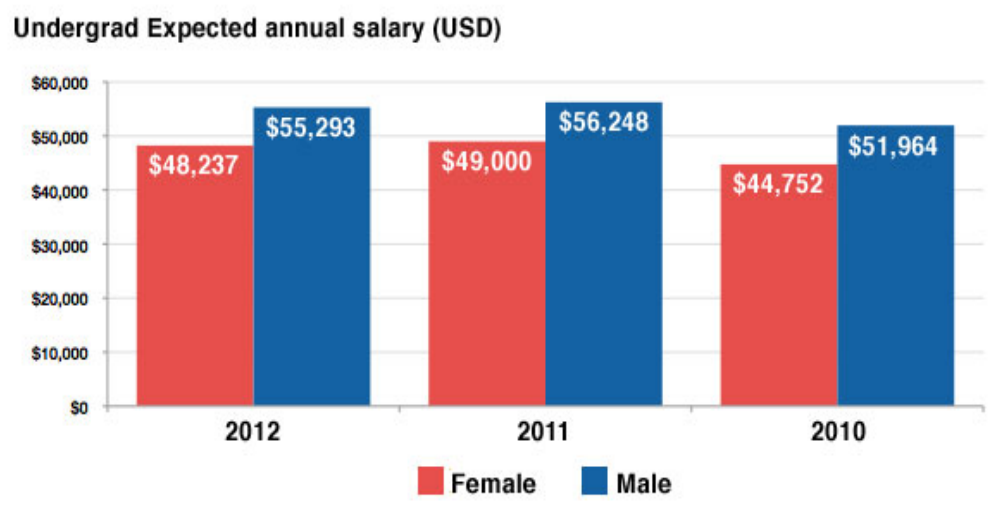

Figure 1. Expected first-year salaries of male and female undergrads

The results of this current study also yielded that millennial females have higher organizational commitment levels than their male counterparts. This can be as a result of the "great recession" that the US is currently dealing with along with an understanding of males dominating the workforce. Thus, women understand that they are a marginalized group in the workforce and are very committed to keeping their job. From a different perspective, women (because of their motherly instincts) tend to treat their organization as their extended family and are very committed to their organization. Some researchers have argued that women are more committed to organizations than men because of the difficulties they must overcome in order to obtain employment (Grusky, 1966; Hrebiniak \& Alutto, 1972). Furthermore, a study by Wahn (1998) found women to be higher in continuance commitment than men. Lastly, Mathieu and Zajac's (1990) meta-analysis of organizational commitment revealed that women are more organizationally committed than men, although the difference was small. Thus, managers should consider hiring millennials with graduate level degrees and more specifically, females because of their higher organizational commitment levels.

There are several limitations to this study. The participants from this study represent a specific population of I.T. employees who all work for the same organization. As mentioned above, a larger sample of participants from different geographic regions may have yielded different results. The results cannot be generalized to all millennials in the workforce. The small sample size is also a limitation. This study should be considered a pilot study for future research endeavors. Lastly, a Likert-type scale for all sections of the research instrument would have been helpful for yielded the severity for each response.

\section{Conclusion}

This study set out to learn more about the millennial generation in the workforce. Millennials are a dynamic force in the workforce and are emerging as leaders. Emegwali (2011) found that Millennials are already taking on leadership roles in both educational reform and in political elections, and concludes that is it not clear how millennials will be remembered by history and that this dynamic population demands accountability, transparency, and change. As the baby boomer generation retires, the next two generations will be planning, organizing, leading, and controlling the workforce. Millennials may have a competitive advantage because of their computer proficiencies. One study concluded that Millennials are more engaged in the newer media, which suggests that "new media will become even more integrated into work processes" (Bott et al., 2011, p. 98). Nevertheless, managers should prepare accordingly for the millennial generation. 


\section{References}

Azalea, A., Omar, F., \& Mastor, K. (2009). The role of individual differences in job satisfaction among Indonesians and Malaysians. European Journal of Social Sciences, 10(4), 496-511.

Bjork, I. T., Samdal, G. B., Hansen, B. S., Torstad, S., \& Hamilton, G. A. (2007). Job satisfaction in a Norwegian population of nurses: A questionnaire survey. International Journal of Nursing Studies, 44, 747-757. http://dx.doi.org/10.1016/j.ijnurstu.2006.01.002

Bott, J., Faulk, D., Guntupalli, A., Devaraj, S., \& Holmes, M. (2011). An examination of generational differences and media exposure. The Journal of Applied Management and Entrepreneurship, 16(4), 78-100.

Casserly, M. (2012). The real origins of the gender pay gap--And how we can turn it around. Retrieved from http://www.forbes.com/sites/meghancasserly/2012/07/05/real-origins-gender-pay-gap-how-we-can-turn-it-a round/

Colquitt, J. A., Lepine, J., \& Wesson, M. J. (2011). Organizational Behavior: Improving Performance and Commitment in the Workplace (2nd ed.). New York, NY: McGraw-Hill/Irwin.

Dols, J., Landrum, P., \& Wieck, K. (2010). Leading and managing an intergenerational workforce. Creative Nursing, 16(2), 68-74. http://dx.doi.org/10.1891/1078-4535.16.2.68

Emeagwali, S. N. (2011). Millennials: Leading the Charge for Change. Techniques, 23-26.

Gentry, W. A., Deal, J. J., Griggs, T. L., Mondore, S. P., \& Cox, B. D. (2011). A comparison of generational differences in endorsement of leadership practices with actual leadership skill level. Consulting Psychology Journal: Practice \& Research, 63(1), 39-49. http://dx.doi.org/10.1037/a0023015

Gibson, W. J., Greenwood, R. A., \& Murphy, E. F. (2010). Analyzing Generational Values among Managers and Non-Managers for Sustainable Organizational Effectiveness. SAM Advanced Management Journal, Winter, $33-43$.

Grusky, D. (1966). Career mobility and organizational commitment. Administrative Science Quarterly, 10, 488-503. http://dx.doi.org/10.2307/2391572

Hartman, J. H., \& McCambridge, J. (2011). Optimizing Millenials' Communication Styles. Business Communication Quarterly, 74(1), 22-44. http://dx.doi.org/10.1177/1080569910395564

Hewlett, S. A., Sherbin, L., \& Sumberg, K. (2009). How generation and baby boomers will reshape your agenda. Harvard Business Review, 71-77.

Howe, N., \& Strauss, W. (2007). Millennials \& K-12 Schools: Educational Strategies for a New Generation. Great Falls: LifeCourse Associates.

Hrebiniak, L. G., \& Alutto, J. A. (1972). Personal and role related factors in the development of organizational commitment. Administrative Science Quarterly, 17, 555-573. http://dx.doi.org/10.2307/2393833

Kane, S. (2012). Generation X. Retrieved from http://legalcareers.about.com/od/practicetips/a/GenerationX.htm

Mathieu, J. E., \& Zajac, D. M. (1990). A review and meta-analysis of the antecedents, correlates, and consequences of organizational commitment. Journal of Applied Psychology, 108, 171-194.

Rosenberg, M. (2009). Baby boom: The population baby boom of 1946-1964 in the United States. Retrieved from http://geography.about.com/od/populationgeography/a/babyboom.htm

Salahuddin, M. M. (2010). Generational differences impact on leadership style and organizational Success. Journal of Diversity Management, 5(2), 1-6.

Simons, N. (2010). Leveraging generational work styles to meet business objectives. Information Management, 44(1), 28-33.

Tolbzie, A. (2008). Generational differences in the workplace. Research and Training Center of Community Living, 19, 1-13.

Wahn, J. C. (1998). Sex differences in the continuance component of organizational commitment. Group \& Organization Management, 23(3), 256-266. http://dx.doi.org/10.1177/1059601198233004 